complex]. Visnyk ekonomiky transportu $i$ promyslovosti, no.62 (Special issue), pp. 151157.

3 Dykan V.L., Maslova V.O. (2013) Orhanizatsiia vyrobnytstva [Organization of production]. Kharkiv: UkrDUZT. (in Ukrainian)

4 Dikan' V.L., Shramenko E.V., Yakimenko N.V. (2012) Ekonomika predpriyatiya [Enterprise economy]. Khar'kov: UkrDAZT. (in Russian)

5 Kalycheva N.Ye., Maslova V.O. (2014) Lohistychni pidkhody, yak osnova ratsionalnoi orhanizatsii vyrobnychoho protsesu na pidpryiemstvi [Logistic approaches as a basis for rational organization of production process at the enterprise]. Visnyk ekonomiky transportu i promyslovosti, no.47, pp. 83-86.

6 Kalycheva N.Ye. (2017) Rol transportno-lohistychnykh system u zabezpechenni stiikoho rozvytku ekonomiky [The role of transport and logistics systems in ensuring sustainable economic development]. Visnyk ekonomiky transportu i promyslovosti, no.58, pp. 103-109.

7 Derzhavna sluzhba statystyky Ukrainy (official site). Available at: http://www.ukrstat.gov.ua (accessed 22 November 2019)

8 Panchenko S.V., Dykan V.L., Volovelska I.V., Maslova V.O. (2017) Upravlinnia biznesom [Business management]. Kharkiv: UkrDUZT. (in Ukrainian)

9 Prodanova L.V., Pankova L.I., Zaiva Yu.O. (2016) Problemni aspekty rozvytku rynku budivelnoi haluzi Ukrainy [Problematic aspects of development of the construction industry market in Ukraine]. Ekonomichnyi visnyk Zaporizkoi derzhavnoi inzhenernoi akademii, Vol. 6-2 (06), pp. 57-61.

10 Tsyfra T.Yu., Zapiechna Yu.O., Hrytsenko O.S. (2018) Ekonomichni pidkhody do formuvannia ta otsinky stratehii budivelnoho pidpryiemstva [Economic approaches to the formation and evaluation of the construction enterprise strategy]. Tekhnolohichnyi audyt ta rezervy vyrobnytstva, no. 39(4), pp. 70-76.

Удк336.71(477)

\title{
КЛІЕНТООРІЕНТОВАНИЙ ПІДХІД ДО ВИЗНАЧЕННЯ СТРАТЕГІЇ РОЗВИТКУ ДІЯЛЬНОСТІ ФІНАНСОВО-КРЕДИТНИХ ОРГАНІЗАЦІЙ
}

\author{
Маслова В.О., к.е.н., доцент, \\ Шиирна М.В., магістр (УкрДУЗТ)
}

У статті обтрунтовано необхідність застосування клієнтоорієнтованого підходу до розробки стратегії розвитку діяльності фінансово-кредитних організацій, зокрема банківських установ. Визначено, щзо застосування саме такого підходу дозволяє не тільки підвищувати рівень їх надійності з точки зору клієнтів, але й вирішити існуючу сьогодні проблему національної економіки, пов'язану з мобілізацією фінансових ресурсів населення, суб'єктів господарювання, капіталізащії банків та підвищення рівня їх конкурентоспроможності на ринку фінансово-кредитних послуг України.

Ключові слова: фінансово-кредитна організація, банк, стратегія розвитку, маркетингова діяльність, клієнтоорієнтований підхід.

(С) Маслова B.О., Шпирна М.B.
Вісник економіки транспорту і промисловості № 68, 2019 


\title{
КЛИЕНТООРИЕНТИРОВАННЫЙ ПОДХОД К ОПРЕДЕЛЕНИЮ СТРАТЕГИИ РАЗВИТИЯ ДЕЯТЕЛЬНОСТИ ФИНАНСОВО-КРЕДИТНЫХ ОРГАНИЗАЦИЙ
}

\author{
Маслова В.А., к.э.н., доцент, \\ Шиирная М.В., магистр (УкрГУЖТ)
}

\begin{abstract}
В статье обоснована необходимость применения клиентоориентированного подхода к разработке стратегии развития деятельности финансово-кредитных организаций, в том числе банковских учреждений. Определено, что применение именно такого подхода позволяет не только повышать уровень их надежности с точки зрения клиентов, но и решить существующую сегодня проблему национальной экономики, связанную с мобилизачией финансовых ресурсов населения, субъектов хозяйствования, капитализаџии банков и повышение уровня их конкурентоспособности на рынке финансово-кредитных услуг Украинь
\end{abstract}

Ключевые слова: финансово-кредитная организация, банк, стратегия развития, маркетинговая деятельность, клиентоориентированный подход.

\section{CLIENT-ORIENTED APPROACH TO DETERMINING THE STRATEGY OF DEVELOPMENT OF ACTIVITIES OF FINANCIAL- CREDIT ORGANIZATIONS}

\author{
Maslova V.O., PhD Econ., associate professor, \\ Shpyrna M.V., master (UkrSURT)
}

The article substantiates the necessity of applying a client-oriented approach to developing a strategy for developing the marketing activities of financial and credit institutions, in particular banking institutions. In today's business environment, financial institutions, like any business entity, must compete to attract potential customers, increase their financial services, and increase their profitability. The analysis of the activity of Ukrainian banks in particular showed a low level of their competitiveness in comparison with foreign banks, the number of which remains quite large in the Ukrainian financial market. The main problem of increasing the competitiveness of domestic banks is the low mobilization of financial resources of the population, economic entities, etc., and the related capitalization of banks.

The main measures of raising the capital of the bank in the current conditions of development of the domestic economy are attracting deposits with capitalization of income and additional issue of shares. The only barrier to using the first method of bank capitalization today is the low level of trust of its clients - individuals and legal entities. The use of the second method - the issue of shares - is nowadays significantly limited due to the underdevelopment of the stock market and the imperfection of the legislation in force in this field. It is concluded that in the difficult conditions of functioning of the financial market and the economy of Ukraine as a whole, in defining a development strategy, it is necessary to use an approach that would maximally satisfy the needs of potential clients of banks, increase their confidence level and allow to increase the volume of using bank services

It is determined that the application of a client-oriented approach allows not only to increase the level of bank reliability from the point of view of clients, but also to solve the existing problem of the national economy related to the mobilization of financial resources of the population, economic entities, capitalization of banks and increase their level of

Вісник економіки транспорту і промисловості № 68, 2019 
competitiveness. market of financial and credit services of Ukraine.

Keywords: financial-credit organization, bank, development strategy, marketing activity, client-oriented approach.

Постановка проблеми. В сучасних умовах діяльності фінансово-кредитні організації, як і будь-який суб'єкт господарювання, повинні вступати у конкурентну боротьбу за залучення потенційних клієнтів, збільшення обсягу надання фінансово-кредитних послуг та отримання приросту прибутковості власної діяльності. Конкурентна боротьба на ринках товарів та послуг реалізується через маркетингову діяльність суб'єкта господарювання та в сучасних умовах ведення бізнесу повинна носити постійний системний характер, щоб забезпечувати виконання цілей організації у збільшенні іiі прибутковості. Таким чином, принципи та підходи до ведення цієї діяльності в умовах жорсткої конкурентної боротьби повинні бути обгрунтовано визначені та закладені в стратегію розвитку будь-якої організації, у тому числі й фінансово-кредитної.

Аналіз останніх досліджень i публікацій показав, що проблемам стратегічного управління розвитком вітчизняних підприємств та організацій, у тому числі фінансово-кредитних установ присвячено досить велика кількість наукових робіт. Серед досліджень за останні роки можна виділити праці Воловельської І. В. [1-3], Диканя В.Л. [3] , Діденко Л.В. [4], Коваленко В.В. [5], Маслової В.О. [2, 3, 7], Татарина Н.Б. [10], Токмакової І.В. [11] та інших. В наведених роботах наголошено на необхідності застосування стратегічного управління діяльністю будь-якого суб'єкта господарювання в сучасних умовах господарювання, визначені особливості стратегічного управління як банківськими, так i небанківськими фінансовокредитними установами, досліджено фактори, що впливають на поведінку споживачів в сучасних умовах при виборі того чи іншого продукту або послуги та розглянуті аспекти стратегічного розвитку в умовах інформатизації суспільства.

Виділення невирішених частин загальної проблеми. У той же час, питання

конкурентоспроможності кредитних організацій формування стратегії розвитку їх діяльності розглядаються не достатньо.

Метою статті $\epsilon$ обгрунтування вибору клієнтоорієнтованого підходу до розробки стратегії розвитку діяльності фінансово-кредитних установ як найбільш доцільного з існуючих в сучасних умовах господарювання в Україні, спрямованого на підвищення їх конкурентоспроможності на ринку фінансових послуг.

Виклад основного матеріалу. Ринок фінансово-кредитних послуг в Україні представлений такими організаціями як депозитні корпорації (державні та комерційні банки, включаючи Національний банк України (НБУ)), страхові компанії, кредитні спілки, ломбарди, недержавні пенсійні фонди та інші [4]. В структурі фінансового ринку країни найбільшу питому вагу займають банки (за даними НБУ на початок 2019 року це більше $85 \%$ як за пасивами, так й активами [8]).За період з 2016 по 2019 роки кількість діючих банків зменшилася на 34,2\% (з 117 банків до 77), у тому числі 3 іноземним капіталом менш ніж на 10\%. I якщо у 2016 році частка банків з іноземним капіталом складала 35\%, то в 2019 році вона зросла до 48\% (незважаючи на скорочення кількості діючих банків 3 іноземним капіталом на фінансовому ринку України) [8].

Наведені дані свідчать про низький рівень конкурентоспроможності вітчизняних банків (із 100\% національним капіталом) порівняно 3 іноземними банками, кількість яких на українському фінансовому ринку, незважаючи на

Вісник економіки транспорту і промисловості № 68, 2019 
нестабільність економічної, соціальної та політичної ситуації в державі, залишається досить великою.

Однією 3 невирішених проблем підвищення конкурентоспроможності вітчизняних банків вважається проблема мобілізації фінансових ресурсів населення, суб'єктів господарювання тощо та пов'язана 3 цим капіталізація банків України [10]. Низький рівень капіталізації банків призводить до підвищення ризиків у банківській діяльності, обмеження асортименту фінансових послуг та збільшення витрат на їх надання. Втрата капіталу робить неможливим функціонування банку і може призвести до його банкрутства.

Основними заходами підвищення капіталу банку в сучасних умовах розвитку вітчизняної економіки $є$ залучення депозитів 3 капіталізацією доходу та додаткова емісія акцій. Депозити 3 капіталізацією доходів передбачають додавання нарахованої суми відсотків за депозитом до основної суми депозиту та подальше нарахування доходів на більшу суму (капіталізація відсотків за депозитом). Єдиним, але переборним сьогодні бар'єром для використання цього методу капіталізації банку є низький рівень довіри його клієнтів - фізичних та юридичних осіб. Використання другого методу - випуск акцій - сьогодні значно обмежений через нерозвиненість фондового ринку та недосконалість діючого у цій сфері законодавства.

Тому, на нашу думку, в умовах, що склалися сьогодні на фінансовому ринку та в економіці України в цілому, при визначенні стратегії розвитку, спрямованої на підвищення конкурентоспроможності та ефективності діяльності фінансовокредитних установ, перш за все банків, варто використовувати підхід, який максимально задовольняв би потреби потенційних клієнтів банків, підвищував рівень їх довіри та дозволяв збільшувати обсяги користування послугами банків.

Сучасна економічна наука виділяє два основних підходи, які можуть бути застосовані у маркетинговій діяльності суб'єктів господарювання, й отже, у конкурентній боротьбі

конкурентоорієнтований

клієнтоорієнтований [7].

В основу конкурентоорієнтованого підходу до визначення стратегії розвитку покладено необхідність дослідження поведінки конкурентів та факторів, що спонукають конкурентів до зміни своєї поведінки на ринку. При цьому під поведінкою конкурента розуміється його ринкова активність, спрямована на розширення або збереження обсягів власної діяльності за рахунок зменшення ринкової долі іншого суб'єкта цього ринку або ринку взаємозамінюваного товару. Головною метою такого підходу $\epsilon$ аналіз дій конкурентів, визначення їх слабких місць та реалізація стратегічних і тактичних дій, які дозволять обійти конкурента, наприклад, за ціною, якістю або асортиментом продукції (послуг). Потім сформувати у споживача уявлення, що саме ця продукція задовольнить якусь його потребу, активно доводячи інформацію до потенційного клієнта про наявність такого товару та ii унікальні відмінності від аналогічної продукції інших товаровиробників на ринку.

Враховуючи специфіку діяльності фінансово-кредитних установ, у тому числі й банків (залучення у вклади грошових коштів фізичних i юридичних осіб та розміщення цих коштів від свого імені, на власних умовах та на власний ризик, відкриття і ведення банківських рахунків фізичних та юридичних осіб), пропонувати будь-які інноваційні продукти-послуги на фінансовому ринку, застосування яких не могли б у найближчій перспективі дозволити конкуренти, є малоймовірним. Тому конкурентоорієнтованого підходу до розробки стратегії розвитку у цій сфері економічної діяльності буде або недоцільним та витратним, або малоефективним.

Вісник економіки транспорту і промисловості № 68, 2019 
Клієнтоорієнтований

підхід спрямований, перш за все, на дослідження поведінки споживачів, визначення факторів, що спонукають їх до зміни своєї поведінки, аналізу їхніх потреб, рівня задоволення цих потреб та орієнтацію політики та стратегії діяльності суб'єкта господарювання саме на задоволення існуючих потреб споживача, клієнта. В основі цього підходу лежить ієрархія потреб Маслоу та визначення потреби як того, що необхідно людині для існування і оптимального функціонування $[2,3,7]$.

Основна потреба споживача (фізичної або юридичної особи) фінансових послуг при виборі того чи іншого банку для ведення власної фінансової діяльності - це, перш за все, його надійність. I чим більшою кількістю фінансових послуг клієнт готовий скористатися чи користується, тим надійнішою вважається для нього ця банківська установа.

На сьогоднішній день банки пропонують своїм клієнтам такі сучасні технології обслуговування як онлайнбанкінг, що дозволяє без відвідування банківської установи здійснювати керування власними рахунками, платежі, отримувати кошти, що надійшли, користуватися кредитними та посередницькими (наприклад страховими, транспортними, поштовими тощо) послугами банку та здійснення інших фінансових операцій у будь-який момент часу, не виходячи з дому або офісу.

Від впровадження дистанційного обслуговування виграють й самі банківські організації, оскільки це дозволяє істотно розширити асортиментну лінійку i привернути увагу нового сегмента клієнтів за допомогою віддалених сервісів, зменшити витрати на здійснення банківської діяльності, пов'язані 3 обслуговуванням клієнтів, розвантажити відділення та забезпечити приблизно однаковий рівень сервісу по всій мережі філій банку.

Крім того, надаючи зручне обслуговування за рахунок онлайн-послуг, банки ненав'язливо вимагають акумулювати вільні грошові кошти клієнтів на карткових рахунках банківської установи, щоб скористатися усіма перевагами дистанційного обслуговування. Це дозволяє підвищити рівень мобілізації фінансових ресурсів у короткостроковому періоді, а отже й підвищити власну конкурентоспроможність на фінансовому ринку країни.

Таким чином, застосування банківськими установами новітніх досягнень цифрової економіки сьогодні дозволяє значно підвищити ефективність діяльності, конкурентоспроможність на ринку фінансових послуг, рівень обслуговування потенційних клієнтів та залучення їх фінансових ресурсів порівняно 3 небанківськими фінансовокредитними установами [11].

Прикладом ефективного дистанційного обслуговування клієнтів на сьогоднішній день $€$ онлайн-банкінг Приват24, а сам Приватбанк завдяки своєму продукту вважається найбільш технологічним, з великою кількістю послуг та надійним для залучення потенційних клієнтів банком країни. Завдяки розвитку технологій дистанційного обслуговування інший державний банк України, Ощадбанк, вийшов у лідери за динамікою приросту депозитів фізичних осіб і майже втричі збільшив свою частку на ринку - 3 7,12\% у 2014 році до 21,92\% на кінець 2018 року [6].

У той же час варто зауважити, що довгострокові депозити, особливо депозити 3 капіталізацією доходів, які необхідні банкам для здійснення кредитування, перш за все, бізнесу та підвищення власної конкурентоспроможності в сучасних умовах соціально-економічного розвитку держави $\epsilon$ недостатньо задіяними. Це пов'язано з нестабільністю економічної та політичної ситуації в країні, зниженням прибутковості діяльності бізнес-структур,

Вісник економіки транспорту і промисловості № 68, 2019 
значним зниженням рівня життя та платоспроможності населення, що не сприяє заохоченню до накопичення грошових коштів на віддалену перспективу.

Ще одним інноваційним впровадженням, спрямованим на підтримку клієнтів та застосування клієнтоорієнтованого підходу до розвитку діяльності банків є створення інклюзивних відділень для клієнтів 3 особливими потребами. Першим в Україні та Східній Європі банком, який відкриває інклюзивні відділення, адаптовані для різних груп населення став Ощадбанк, що дозволило йому збільшити свою частку на ринку фінансових послуг, вартість корпорації та конкурентоспроможність в цілому за рахунок збільшення потоку клієнтів серед певного сегменту населення [9].

Висновок.

застосування

Таким

чином, клієнтоорієнтованого підходу до визначення стратегіï розвитку фінансово-кредитних установ, і перш за все основних акумуляторів грошових коштів банків, дозволяє не тільки підвищити їх надійність 3 точки зору клієнтів, але й вирішити одну 3 головних фінансових проблем національної економіки, пов'язану 3 мобілізацією фінансових ресурсів населення, суб'єктів господарювання тощо, капіталізації банків та підвищення рівня конкурентоспроможності останніх особливо на ринку фінансово-кредитних послуг України.

\section{ПЕРЕЛІК ВИКОРИСТАНИХ ДЖЕРЕЛ}

1 Воловельская И. Анализ состояния банковской системы Украины в современных условиях / И. Воловельская, В. Петров, А. Марковский // Вісник економіки транспорту і промисловості. 2018. - №63. - С.270-275.

2 Воловельська I.В. Дослідження факторів, що впливають на поведінку споживачів в сучасних умовах / І.В.Воловельська, В.О.Маслова // Вісник економіки транспорту і промисловості. 2018. - №61. - C.117-123.

3 Панченко С,В. Управління бізнесом: підручник /С.В.Панченко, В.Л.Дикань, I.В.Воловельська, В.О.Маслова. - Х.: УкрДУЗТ, 2017. - 315 с. 4 Діденко Л.В. Дослідження діяльності небанківських фінансових установ як учасників сучасного ринку фінансових послуг / Л.В.Діденко, I.А.Кобзар, I.С.Ханалієва // Економічний аналіз. - 2018. - Том 28. - № 4. - С. 88-94.

5 Коваленко В.В. Методологічні підходи до формування маркетингових стратегій розвитку інноваційної діяльності банків/ В.В.Коваленко. В.Г.Піддубна //Майбутнє банкінгу: сучасні виклики та перспективи розвитку: зб. матеріалів II Міжнародної науково-практичної інтернет-конференції; 15 червня 2017 року, м. Київ. - К. : КНЕУ, 2017. - С. 76-79.

6 Консолідований звіт про управління АТ «Ощадбанк»: затверджено постановою правління АТ «Ощадбанк» від 25 квітня 2019 року № 281 [Електронний ресурс]. Режим доступу: https://www.oschadbank.ua/ sites/default/files/2019-

04/oschadbank_report-0426_new_2in1.pdf

(дата звернення: 10 листопада 2019)

7 Маслова В.О. Основні підходи до розробки маркетингової стратегії підприємства / В.О. Маслова, І.В. Сапієнко. // Вісник економіки транспорту i промисловості. - 2018. - № 64. - С.277-283.

8 Офіційний сайт Національного банку України [Електронний ресурс]. Режим доступу: https://bank.gov.ua (дата звернення: 10 листопада 2019).

9 Ощадбанк першим в Україні пройшов аудит інклюзивності [Електронний ресурс]. - Режим доступу: https://nabu.ua/ua/oshchadbank-pershim-vukrayini-proyshov.html (дата звернення: 10 листопада 2019).

10 Татарин Н.Б. Проблеми фінансового ринку України та шляхи їх подолання / Н.Б. Татарин, Т.I. Чоп // Економіка і суспільство. - 2018. - Вип. 19. - C. 1169-1174.

Вісник економіки транспорту і промисловості № 68, 2019 
11 Токмакова I.B. Стратегічне управління розвитком підприємств в умовах цифровізації економіки / I.B. Токмакова, Д.А. Шатохіна, С.В. Мельник // Вісник економіки транспорту i промисловості. - 2018. - № 64. - С.283-291.

\section{REFERENCES}

1 Volovel'skaya I., Petrov V., Markovskiy A. (2018) Analiz sostoyaniya bankovskoy sistemy Ukrainy v sovremennykh usloviyakh [Analysis of the state of the banking system of Ukraine in modern conditions]. Visnyk ekonomiky transportu $i$ promyslovosti, no.63, pp.270-275.

2 Volovelska I.V., Maslova V.O. (2018) Doslidzhennia faktoriv, shcho vplyvaiut na povedinku spozhyvachiv $\mathrm{v}$ suchasnykh umovakh [Investigation of the factors influencing consumer behavior in modern conditions]. Visnyk ekonomiky transportu $i$ promyslovosti, no.61, pp.117123.

3 Panchenko S.V., Dykan V.L., Volovelska I.V., Maslova V.O. (2017) Upravlinnia biznesom [Business management]. Kharkiv: UkrDUZT. (in Ukrainian)

4 Didenko L.V., Kobzar I.A., Khanaliieva I.S. (2018) Doslidzhennia diialnosti nebankivskykh finansovykh ustanov yak uchasnykiv suchasnoho rynku finansovykh posluh [Research of the activity of non-bank financial institutions as participants of the modern financial services market]. Ekonomichnyi analiz, vol. 28, no.4, pp. 88-94.

5 Kovalenko V.V., Piddubna V.H. (2018) Metodolohichni pidkhody do formuvannia marketynhovykh stratehii rozvytku innovatsiinoi diialnosti bankiv [Methodological approaches to the formation of marketing strategies for the development of innovative activities of banks]. Proceedings of the Maibutnie bankinhu: suchasni vyklyky ta perspektyvy rozvytku: II Mizhnarodna naukovo-praktychna internet-konferentsiia (Ukraine, Kyiv, June 15, 2017), Kyiv: KNEU, pp. 76-79.

6 Konsolidovanyi zvit pro upravlinnia AT «Oshchadbank» [Consolidated Management Report of Oschadbank JSC]. Oschadbank [Oschadbank] (official site). Available at: https://www.oschadbank.ua/sites/default/files 12019-04/oschadbank_report-

0426_new_2in1.pdf (accessed 10 November 2019)

7 Maslova V.O., Sapiienko I.V. (2018) Osnovni pidkhody do rozrobky marketynhovoi stratehii pidpryiemstva [Basic approaches to the development of enterprise marketing strategy]. Visnyk ekonomiky transportu i promyslovosti, no.64, pp. 277283.

8 Natsionalnyi bank Ukrainy [National Bank of Ukraine] (official site). Available at: https://bank.gov.ua (accessed 10 November 2019).

9 Oshchadbank pershym v Ukraini proishov audyt inkliuzyvnosti [Oschadbank was the first in Ukraine to pass the inclusivity audit]. Natsionalne antykoruptsiine biuro Ukrainy [National Anti-Corruption Bureau of Ukraine] (official site). Available at: https://nabu.ua/ua/oshchadbank-pershim-vukrayini-proyshov.html (accessed 10 November 2019)

10 Tataryn N.B., Chop T.I. (2018) Problemy finansovoho rynku Ukrainy ta shliakhy yikh podolannia [Problems of the financial market of Ukraine and ways to overcome them]. Ekonomika i suspilstvo, vol. 19, pp. 1169-1174.

11 Tokmakova I.V., Shatokhina D.A., Melnyk S.V. (2018) Stratehichne upravlinnia rozvytkom pidpryiemstv $\mathrm{V}$ umovakh tsyfrovizatsii ekonomiky [Strategic management of enterprise development in the conditions of digitalization of economy]. Visnyk ekonomiky transportu i promyslovosti, no.64, pp.283-291. 